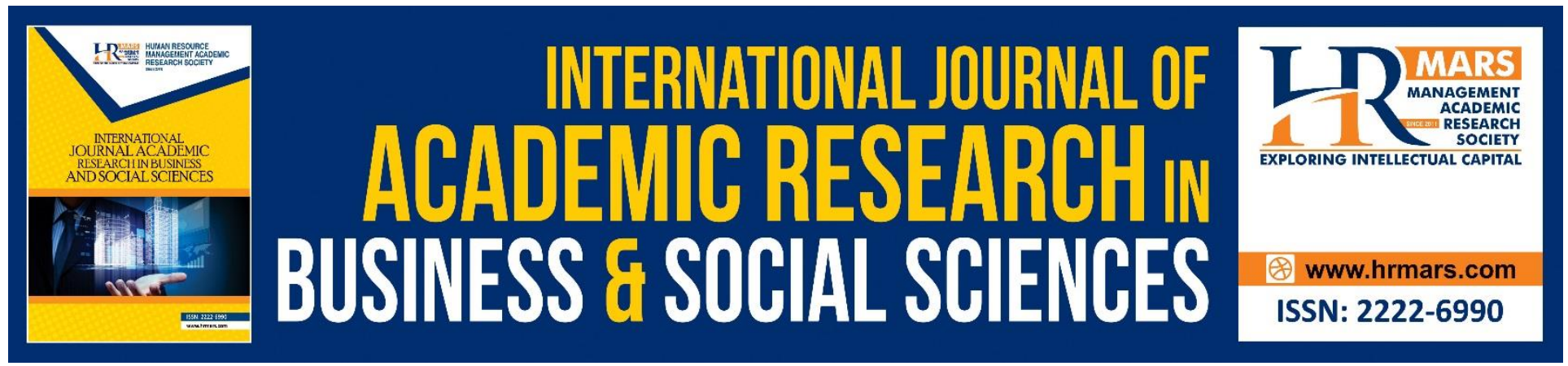

\title{
An Empirical Examination of Undergraduate Accounting Students' Ethical Judgment: Malaysia Evidence
}

Razana Juhaida Johari, Norfadzilah Rashid, Ahmad Shukri Yazid, Fauzilah Salleh

To Link this Article: http://dx.doi.org/10.6007/IJARBSS/v8-i12/5064 DOI: $10.6007 /$ IJARBSS/v8-i12/5064

Received: 07 Nov 2018, Revised: 18 Dec 2018, Accepted: 28 Dec 2018

Published Online: 29 Dec 2018

In-Text Citation: (Johari, Rashid, Yazid, \& Salleh, 2018)

To Cite this Article: Johari, R. J., Rashid, N., Yazid, A. S., \& Salleh, F. (2018). An Empirical Examination of Undergraduate Accounting Students' Ethical Judgment: Malaysia Evidence. International Journal of Academic Research in Business and Social Sciences, 8(12), 669-681.

Copyright: (C) 2018 The Author(s)

Published by Human Resource Management Academic Research Society (www.hrmars.com)

This article is published under the Creative Commons Attribution (CC BY 4.0) license. Anyone may reproduce, distribute, translate and create derivative works of this article (for both commercial and non-commercial purposes), subject to full attribution to the original publication and authors. The full terms of this license may be seen

at: http://creativecommons.org/licences/by/4.0/legalcode

Vol. 8, No. 12, 2018, Pg. 669 - 681

http://hrmars.com/index.php/pages/detail/IJARBSS

JOURNAL HOMEPAGE

Full Terms \& Conditions of access and use can be found at http://hrmars.com/index.php/pages/detail/publication-ethics 


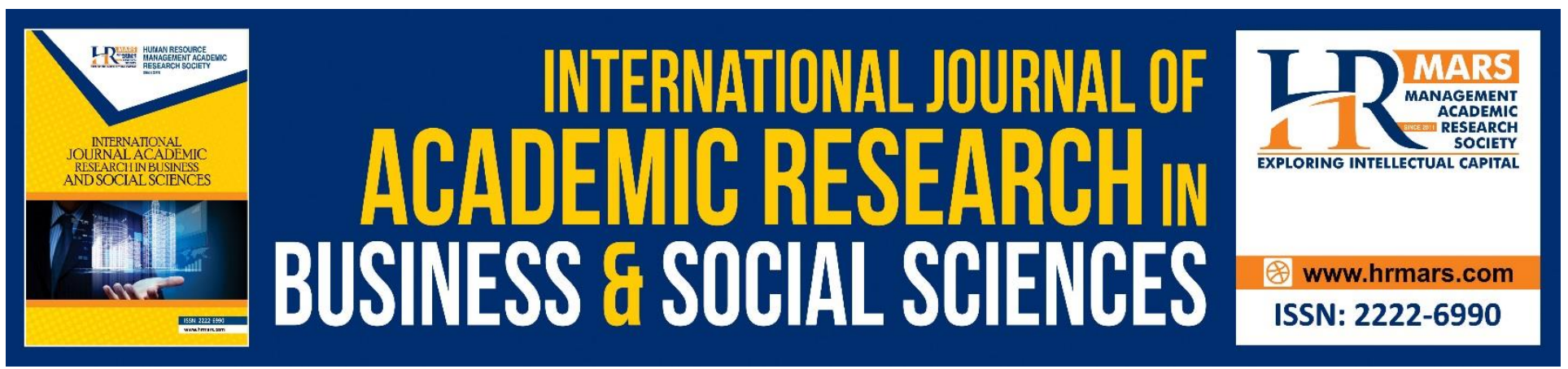

\title{
An Empirical Examination of Undergraduate Accounting Students' Ethical Judgment: Malaysia Evidence
}

\author{
${ }^{1}$ Razana Juhaida Johari, ${ }^{2}$ Norfadzilah Rashid, ${ }^{3}$ Ahmad Shukri Yazid, \\ ${ }^{4}$ Fauzilah Salleh \\ ${ }^{a}$ Faculty of Accountancy, UiTM Shah Alam, Malaysia \\ ${ }^{\mathrm{b}}$ Faculty Economics \& Management Sciences, Universiti Sultan Zainal Abidin, Malaysia \\ Corresponding Author: nikmfadzilah@unisza.edu.my
}

\begin{abstract}
Several highly publicized financial disasters in the past decade have brought into question the auditors' integrity and credibility especially related to their ethical judgment. More specifically, misconduct of auditors, has drawn significant attention to the importance of ethics and integrity in public accounting. As a result, accounting firms have taken actions to re-establish credibility within the profession. In the wake of the aforementioned accounting scandals, many authors have argued that ethics education should start early in an auditors career, even before joining the profession. Noting the importance of moral intensity construct and ethical orientation dimensions in shaping the auditors' ethical judgment, this current study provides further evidence by investigating these two variables on future auditors' ethical judgment. The Structural Equation Modeling (SEM) technique is used to silmutaneously analyze the data as to establish a behavioral model of future auditors' ethical judgment. The findings showed that the moral intensity and ideologistic ethical orientation influences the future auditors' ethical judgments, but not the relativistic ethical orientation. Implications of the findings and future research are discussed in the paper. The findings could contribute to the existing literature on ethics within the academic curriculum and, in particular, to accounting ethics in Malaysia.
\end{abstract}

Keywords: Accounting Ethics, Education, Moral Intensity, Ethical Orientation, Auditing Students.

\section{Introduction}

The failure of some large companies in the west (Enron, WorldCom and Lehman Brothers) as well as in Malaysia (Perwaja Steel Berhad, Transmile Group Berhad, PKFZ Berhad) without auditors warning raised serious questions concerning the ethicality of the auditors. In performing their duties, auditors are often faced with situation involving financial integrity thus; their ethical considerations are often 
challenged. As auditor, their ethical judgment have to meet up with both ethical obligation (between auditors \& public) and contractual obligation (between auditors \& management), and this is where the auditors conflict will arise (Westra, 1986). The conflicts of interest among the client firm, the public, the audit firm and the auditing profession provide the bases for many of the potential ethical issues that auditors must resolve within their profession. In understanding the ethical judgment of an individual, Jones (1991) argued that one should recognized and investigated the specific characteristics of moral issues (moral intensity) together with other personal and situational factors. According to Jones (1991), the moral intensity of the issue captures the heightened feelings and emotions of a particular ethical conflict and there are certain properties within an ethical issue that make the issue more salient and vivid to the decision-maker.

The ethical judgment also tends to vary according to personal ethical orientation which comprised of two underlying components i.e. idealism and relativism (Forsyth, 1980). Current theoretical views maintain that an individual's personal ethical orientation influences ethical judgment of professionals including accountants (e.g. Greenfield et al., 2008). The differences in ethical orientation can result in disagreements about what is ethical per se, about the situations to which a person should be sensitive and about the ethical judgment made. In enhancing the public confidence towards the auditing profession, various guidelines such as Sarbanes Oxley Act (2002) has been imposed on the profession. Continuing the effort that have been taken by the regulators and audit firms, accounting educators were also placed their concerns on the matters that involving the nurturing of ethical influences among the accounting students. As accounting students are the future practitioners in their field and their current attitudes could translate into their future behavior in the business world (Ludlum \& Moskaloinov, 2005), those who will be hiring accounting students will have an interest in their ethical orientation, especially in view of recent accounting scandals. Therefore, researchers in business schools have responded to this growing concern by introducing courses in ethics and by developing functional models to better understand an individual's ethical judgment. However, a recent review of the empirical literature on ethical judgment (Uysal, 2010) noted that there is little empirical research directed toward testing such relationships in developing countries such as Malaysia.

Noting the importance of moral intensity construct and ethical orientation dimensions in shaping the auditors ethical judgment, this current study is developed to provide further evidence by investigating these two variables on the future auditors' ethical judgment. In particular, the objective of this study is to identify how the differences in ethical orientation and the perceptions of moral intensity could influence the future auditors' judgment. It sought to contribute to the existing literature on ethics within the academic curriculum and, in particular, to focus on ethics in accounting in Malaysia.

\section{Literature Review \& Development of Hypotheses Ethical Judgment}

According to Hunt and Vitell (1986), the ethical judgments is the stage where a person has recognized the ethical issues and considers alternatives that best solve the problem to attain the most beneficial outcome. The judgments are formed after taking all the considerations of what are morally right and wrong in the context of acceptable standards. 


\section{Moral Intensity}

The moral intensity construct in Jones (1991) issue-contingent model refers to the extent or degree of issue-related moral imperative in a situation. The core concept of this model, moral intensity, claims that one's perception, evaluation and response to a moral issue stem from characteristics of the issue itself. Jones (1991) argued that the moral intensity of an issue would influence the recognition of an issue as an ethical problem and the subsequent behavior in which the decision maker engages. The moral intensity is a multidimensional construct consisting of six issue contingencies i.e. magnitude of consequences, social consensus, temporal immediacy, proximity, probability of effect and concentration of effect (Jones, 1991).

Previous studies have found some significant effect of the moral intensity components on the ethical judgment made by auditors (Cohen \& Bennie, 2006) and accounting students (Sweeney \& Costello, 2009). Similar to the researchers done in business/marketing area, the components of magnitude of consequences and social consensus are proven as the two most significant components that could influence the auditors' ethical judgment followed by the component of probability of effect. In addition, research using the moral intensity construct in auditing is still developing (Cohen and Bennie, 2006). Therefore, based on the preceding discussion, the following hypotheses will be investigated:

H1: Moral intensity is positively associated with ethical judgment.

\section{Ethical Orientation}

Ethical orientation is conceptualized by Forsyth (1980), is based on the philosophical theories of deontology, teleology and ethical skepticism. In 1980, Forsyth developed the Ethics Position Questionnaire (EPQ) to identify an individual's personal ethical orientation. Forsyth (1980) proposes that differences in individual's personal ethical orientation can be parsimoniously described by the degree to which they are idealistic or relativistic. Idealism referred to an individual believes that ethically correct actions will consistently produce desirable outcomes whereas relativism represents an individual's concern for a universal set of rules or standards (Forsyth, 1980).

Empirically, studies using the EPQ help to explain a variety of decisions that individuals make in organizations (e.g. Marques \& Pireira, 2009). In general, the research indicates that relativistic individuals judge ethically uncertain actions more leniently whereas an idealistic individual are harsher on any unethical actions. Fernando \& Chowdhury (2010) results revealed that spiritual wellbeing is strongly correlated only with the idealism orientation. In respect to the accounting ethics, the EPQ instrument has been used in prior studies (e.g. Marques \& Pereira, 2009; Greenfield et al., 2008). Greenfield et al. (2008) found a significant relationship between tax practitioners' ethical orientation and ethical judgment.

Marques \& Pereira (2009) have provided the dissimilar results to previous researches. Their results indicated that older respondents were significantly more relativistic than younger one and those respondents ethical decision making did not differ significantly based on their ethical orientation, neither idealism nor relativism. Therefore, based on the preceding discussion, the following hypotheses will be tested:

$\mathrm{H} 2$ : Idealistic ethical orientation has a positive relationship with ethical judgment.

H3: Relativistic ethical orientation has a negative relationship with ethical judgment. 
INTERNATIONAL JOURNAL OF ACADEMIC RESEARCH IN BUSINESS AND SOCIAL SCIENCES

Vol. 8, No. 12, Dec, 2018, E-ISSN: 2222-6990 @ 2018 HRMARS

\section{Methodology}

\section{Sample}

The population for this study is the final year accountancy students at all branches of Universiti Teknologi MARA (UiTM), Malaysia that enrolled accounting programs. This is justified on the fact that UITM is the public university which provides the most accounting graduates in the country. The sampling frame is based on the number of students taking the Advanced Auditing subject in two consecutive academic semesters i.e. September 2013 - Jan 2014 and March 2014 - July 2014. All the participants have undergone a six-month practical training in various audit firms in Malaysia.

\section{Data Collection}

Data for this study were collected by survey method. Questionnaires were distributed in the selected UiTM branch campuses during their audit class with the assistance of the respective contact person. The sessions were being observed by the contact person in order to assist them in answering the questionnaires. This approach was taken to increase the response rate and to minimize incorrect responses due to respondents misunderstanding some questions (Keller \& Warrack, 2003). Out of 220 copies questionnaires distributed, 12 questionnaires could not be used due to incomplete responses. As a result, a total number of questionnaires analyzed were 188 which indicate a response rate of 85.5 percent.

\section{Variable and Measurements}

This study uses ethical judgment as dependent variable, moral intensity and ethical orientation as independent variables. Below are the discussions on the measurement of each variable under study.

Ethical Judgments - The ethical judgments were measured by asking the respondents' level of agreement with the action statement in the two scenarios (underreporting of time and noncompliance). The issue of non-compliance (Scenario 2) is regarded as having more ethical concern among the auditors as compared to the issue of underreporting of time (Scenario 1). Responses to the above measurement was made on seven-point scale ( 1 = strongly disagree; 7 = strongly agree).

Moral Intensity- The components of moral intensity were measured using a 12 -items (2 items per component) based on Jones' (1991) and adapted from previous research (Johari et al., 2013; Singhapakdi et al., 1996; McMahon \& Harvey, 2006). The 12-items measurement was also made on seven-point scale ( 1 = strongly disagree; 7 = strongly agree).

Ethical Orientation - Ethical orientation is measured by using instrument developed by Forsyth (1980). A 20-question consisted of 10 questions each on idealism (IEO) and relativism (REO) were used to identify the respondent's ethical orientation. Responses to Forsyth instrument was made on seven-point scale (1=strongly disagree; $7=$ =strongly agree).

\section{Instrumentation (The Questionnaire)}

The survey instrument consisted of three primary sections. The first section contained two audit scenarios namely Scenario 1 and Scenario 2. The reason of having two audit scenarios is to provide a 
robust analysis on the process of making ethical judgments, as in exercising the actual duties, auditors deal with different ethical issues. Both of the scenarios are adopted from Johari et al., (2013).

Scenario One is regarding the ethical dilemma related to underreporting time spent on audit task. Due to Ponemon (1992), underreporting of time may be perceived as having low ethical issue as it occurs frequently within audit firm and it may be perceived as part of audit firm culture. On the other hand, Scenario Two describes the ethical dilemma of non-compliance issue. The noncompliance issue is an important auditing issue because the primary purpose of the audit engagement is to ensure that management's assertions are in compliance with generally accepted accounting principles (Ziegenfuss \& Singhapakdi, 1994). Therefore, it is regarded as having high ethical issue in auditing.

The second section of the questionnaires contains a set of 20-questions (10 questions each on idealism and relativism, respectively) of Forsyth's instrument is used to identify the ethical orientation of the respondents. Finally, in the last section i.e. Section C, is designed to obtain respondent's profile such as gender, race, age and audit firm category (big, medium and small audit firm) during practical training. The research instrument requires approximately 15 to 20 minutes to be completed by the respondents.

\section{Statistical/Data Analysis}

This study examines the effects of moral intensity and ethical orientation on ethical judgments by utilizing two statistical techniques. The Statistical Package for Social Sciences (SPSS) is used to analyze the preliminary data and provide descriptive analyses. Besides, the Structural Equation Modeling (SEM) is used to analyze the hypothesized relationships in this study. The selection of the data analysis technique was based on the ability of the technique to produce reliable and valid results.

\section{Results and Discussion \\ Demography of Participants}

The sample in this study comprised of 188 final year accounting students. $98 \%$ of the participants are Malays and only $2 \%$ are from other Bumiputera races. The average age of respondents is 23.2 years old with a standard deviation of 1.02. All the respondents have undergone a - six months practical training in the public audit firms in Malaysia. Majority of them (47\%) have done it at a medium-sized audit firm, followed by $43 \%$ at a small-sized audit firm and only $10 \%$ of the respondents have performed their practical training at a Big Four audit firm. Finally, 70\% of the respondents involved in doing auditing tasks during their internship program.

\section{Descriptive Statistics}

The descriptive statistics of the variables under study is shown in Table 1. As depicted in Table 1, respondents reported relatively higher mean value of ethical judgment and moral intensity in scenario 2, which validates the ethical nature of the issues addressed in both of the scenarios. Scenario 2 is regarded as having higher level of ethical judgment as compared to Scenario 1. Thus, this reflects the earlier note in this study that the issue of non-compliance (Scenario 2) is regarded as having more ethical concern among the auditors as compared to the issue of underreporting of time. The higher ethical issues thus rationalize of the higher moral intensity's mean score in scenario 2. 
INTERNATIONAL JOURNAL OF ACADEMIC RESEARCH IN BUSINESS AND SOCIAL SCIENCES

Vol. 8, No. 12, Dec, 2018, E-ISSN: 2222-6990 @ 2018 HRMARS

Table 1: Descriptive Statistics

\begin{tabular}{lcc}
\hline Variables & Mean & Std. Dev. \\
\hline EJ 1 & 5.03 & 1.72 \\
EJ 2 & 5.49 & 1.77 \\
MI 1 & 4.31 & 0.56 \\
MI 2 & 4.36 & 0.66 \\
IEO & 5.12 & 0.85 \\
REO & 4.60 & 0.65 \\
\hline
\end{tabular}

Note: $\mathrm{EJ}=$ Ethical Judgment, IEO = Idealism Ethical Orientation, REO = Relativism Ethical Orientation

The values of the two dimensions of ethical orientation are obtained by averaging the respective scores of question items. Scores for these variables range from "1" (strongly disagree) to "7" (strongly agree). The mean value for IEO is 5.12 whereas the mean value of REO is 4.60 . Overall, all the respondents have higher levels of IEO compared to REO, which indicates that in making ethical judgment, the respondents are more concern of the human welfare to others.

\section{Hypotheses Testing}

This study applied two-stage modelling which involves the process of developing the measurement model (CFA), before proceeding to test the structural model (Anderson \& Gerbing, 1988). Each of the constructs in this study (i.e. moral intensity, idealism and relativism) was analysed in a separate measurement model (CFA) for Scenario 1 and Scenario 2. In any case, where the results were found not to be consistent with an a priori specified measurement model, the measurement model was specified again and reanalysed (Saidon et al., 2012; Kline, 2005; Tabachnick \& Fidell, 2001). Following the CFA, the hypotheses then were tested using the structural model. As this study are testing the proposed hypotheses by using the two scenarios with different level of auditing issue, a separate analysis for each scenario is conducted respectively.

\section{Stage One: Measurement Model}

\section{Measurement Model 1 (Scenario 1)}

The goodness-of-fit (GOF) indices suggest that the measurement model for Scenario 1 represents a satisfactory fit to the data and that the results of all the fit indices as portrayed in Table 2 achieved the adequate fit except the chi-square value $\left(\chi^{2}=138.789, \mathrm{df}=62, p=0.000\right)$. The results indicated that standardized parameter estimates were all significant $(p<.05)$ with $\mathrm{GFI}=.903, \mathrm{CFI}=.905, \mathrm{IFI}=$ .907 and RMSEA $=.08$. In addition, the inter correlations among the constructs were lesser than 0.85 , demonstrating a lack of discriminant validity. 
INTERNATIONAL JOURNAL OF ACADEMIC RESEARCH IN BUSINESS AND SOCIAL SCIENCES Vol. 8, No. 12, Dec, 2018, E-ISSN: 2222-6990 C 2018 HRMARS

Table 2: Summarized results for Measurement Model 1

\begin{tabular}{|c|c|c|c|c|c|}
\hline Construct & $\begin{array}{l}\text { Factor } \\
\text { Loadin } \\
\mathrm{g}\end{array}$ & $\mathrm{R}^{2}$ & CR & AVE & $\begin{array}{c}\text { Cronbach's } \\
\text { Alpha }\end{array}$ \\
\hline Idealism & & & 0.934 & 0.672 & 0.790 \\
\hline 1. IDL1 & 0.62 & .384 & & & \\
\hline 2. IDL3 & 0.55 & .302 & & & \\
\hline 3. IDL4 & 0.76 & .577 & & & \\
\hline 4. IDL5 & 0.86 & .739 & & & \\
\hline 5. IDL6 & 0.75 & .562 & & & \\
\hline 6. IDL8 ${ }^{b}$ & 0.73 & .532 & & & \\
\hline 7. IDL10 & 0.58 & .336 & & & \\
\hline Relativism & & & 0.925 & 0.642 & 0.749 \\
\hline 1. $\mathrm{RLT}^{\mathrm{b}}$ & 0.73 & .532 & & & \\
\hline 2. RLT3 & 0.54 & .291 & & & \\
\hline 3. RLT5 & 0.54 & .291 & & & \\
\hline Moral Intensity & & & 0.925 & 0.674 & 0.732 \\
\hline 1. $\mathrm{MI} \mathrm{POE}^{\mathrm{b}}$ & 0.67 & .449 & & & \\
\hline 2. MI1COE & 0.87 & .757 & & & \\
\hline 3. MIPX & 0.79 & .624 & & & \\
\hline \multicolumn{6}{|c|}{$\begin{array}{c}\text { Overall Goodness-of-Fit (GOF) Indices: } \\
\chi^{2}=138.789, \mathrm{df}=62, \mathrm{p}=.000, \chi^{2} / \mathrm{df}=2.239 \\
\mathrm{FI}=.903, \mathrm{CFI}=.905, \mathrm{IFI}=.907 \text { and } \mathrm{RMSEA}=.081\end{array}$} \\
\hline
\end{tabular}

All constructs indicated that the Cronbach Alphas were above 0.70. Meanwhile, construct reliability (CR) and average variance extract (AVE) were above 0.50 . Furthermore, all the standardized factor loadings for the constructs were all higher than the recommended level of 0.50 . In conclusion, full measurement model 1 exhibited strong evidence of uni-dimensionality, convergent validity and construct reliability. Therefore, it has adequate measurement properties and is qualified to proceed to the second stage of the analytical process, namely the structural model evaluation.

\section{Measurement Model 2 (Scenario 2)}

Table 3 summarized the results for measurement model 2 . Though the chi-square value indicates a significant value $\left(\chi^{2}=145.204, d f=74, p=0.000\right)$, the GOF indices suggest that the model fit. Again, as in the measurement model 1 , all the standardized parameter estimates in full measurement model 2 were all significant $(p<.05)$ and the values of GOF i.e. GFI, CFI and IFI are above the recommended level of 0.90 . 
INTERNATIONAL JOURNAL OF ACADEMIC RESEARCH IN BUSINESS AND SOCIAL SCIENCES Vol. 8, No. 12, Dec, 2018, E-ISSN: 2222-6990 @ 2018 HRMARS

Table 3: Summarized results for Measurement Model 2

\begin{tabular}{|c|c|c|c|c|c|}
\hline Construct & $\begin{array}{l}\text { Factor } \\
\text { Loading }\end{array}$ & $R^{2}$ & $\mathrm{CR}$ & AVE & $\begin{array}{c}\text { Cronbach's } \\
\text { Alpha }\end{array}$ \\
\hline Idealism & & & 0.923 & 0.636 & 0.790 \\
\hline IDL1 & 0.62 & .384 & & & \\
\hline IDL3 & 0.55 & .302 & & & \\
\hline IDL4 & 0.76 & .577 & & & \\
\hline IDL5 & 0.86 & .739 & & & \\
\hline IDL6 & 0.75 & .562 & & & \\
\hline IDL8 ${ }^{b}$ & 0.73 & .532 & & & \\
\hline IDL10 & 0.58 & .336 & & & \\
\hline Relativism & & & 0.926 & 0.643 & 0.823 \\
\hline $\mathrm{RLT}^{\mathrm{b}}$ & 0.73 & .532 & & & \\
\hline RLT3 & 0.54 & .291 & & & \\
\hline RLT5 & 0.54 & .291 & & & \\
\hline Moral Intensity & & & 0.910 & 0.629 & 0.861 \\
\hline $\mathrm{MI}^{2} \mathrm{POE}^{\mathrm{b}}$ & 0.85 & .714 & & & \\
\hline $\mathrm{MI} 2 \mathrm{COE}$ & 0.75 & .565 & & & \\
\hline $\mathrm{MI} 2 \mathrm{PX}$ & 0.71 & .505 & & & \\
\hline \multicolumn{6}{|c|}{ Overall Goodness-of-Fit (GOF) Indices: } \\
\hline
\end{tabular}

As shown in the Table 3, all the Cronbach Alphas, CR and AVE were also above the recommended level of fitness as specified in Hair et al., (2010). All the standardized factor loadings for the constructs were also higher than 0.50 , whereas the inter-correlations among the constructs were lesser than 0.85 , demonstrating a lack of discriminant validity. The results of the CFA also qualified the measurement properties of Scenario 2 to proceed to the second stage of SEM analysis i.e. the structural model evaluation.

\section{Stage 2: Structural Model}

\section{Structural Model 1 (Scenario 1)}

The model indicates an acceptable $\chi^{2} / \mathrm{df}$ index of 2.578 , which is below the 3.0 threshold value. Other fit indices, $\mathrm{GFI}=.921, \mathrm{CFI}=.900, \mathrm{AGFI}=.908$ and $\mathrm{IFI}=.935$, are all above the threshold value of .9 . The RMSEA of .067 is within the acceptable range of .03 and .08 . Thus, the GOF indicated that the data are fit for the model. In testing the hypothesized model for scenario 1 , the results indicated that all the hypotheses were statistically significant $(\mathrm{H} 1: \beta=.56, \mathrm{H} 3: \beta=54)$ except for $\mathrm{H} 2(\beta=.26)$. Table 4 provides the summary of the hypothesis testing. 
INTERNATIONAL JOURNAL OF ACADEMIC RESEARCH IN BUSINESS AND SOCIAL SCIENCES

Vol. 8, No. 12, Dec, 2018, E-ISSN: 2222-6990 C 2018 HRMARS

\section{Structural Model 2 (Scenario 2)}

The summary provided in the Table 5 also shos that the indices for GOF indicated that the structural model 2, fits the data well. It is identified that the $\chi^{2} / \mathrm{df}=2.130$, which is less than 3.0 and all of the GOF indices marked higher than $.9(\mathrm{GFI}=.901, \mathrm{CFI}=.903, \mathrm{AGFI}=.924$ and $\mathrm{IFI}=.904)$. The RMSEA is equal to .078, which is within the acceptable range. As shown in the Table 4, all the hypotheses are statistically significant except for the hypotheses of $\mathrm{H} 2(\mathrm{H1}: \beta=.22, \mathrm{H} 2: \beta=.20$ and $\mathrm{H3}: \beta=.59)$.

Table 4: Hypotheses Testing

\begin{tabular}{|c|c|c|c|c|}
\hline \multicolumn{5}{|c|}{ (Scenario 1) } \\
\hline $\begin{array}{l}\text { Hypothes } \\
\text { es }\end{array}$ & Path & $\begin{array}{c}\text { Standardize } \\
\mathrm{d} \\
\text { Coefficient }\end{array}$ & $\begin{array}{c}\text { Critical } \\
\text { Ratio } \\
\text { (t-value) }\end{array}$ & Result \\
\hline $\mathrm{H} 1$ & $\begin{array}{l}\text { Moral Intensity } \rightarrow \\
\text { Ethical Judgment }\end{array}$ & .54 & $3.09 * *$ & $\begin{array}{c}\text { Significa } \\
\text { nt }\end{array}$ \\
\hline $\mathrm{H} 2$ & $\begin{array}{l}\text { Idealism } \rightarrow \text { Ethical } \\
\text { Judgment }\end{array}$ & .56 & $2.98 * *$ & $\begin{array}{c}\text { Significa } \\
\text { nt }\end{array}$ \\
\hline $\mathrm{H} 3$ & $\begin{array}{l}\text { Relativism } \rightarrow \\
\text { Ethical Judgment }\end{array}$ & .26 & 1.16 & $\begin{array}{c}\text { Not } \\
\text { Significa } \\
\text { nt }\end{array}$ \\
\hline
\end{tabular}

(Scenario 2)

\begin{tabular}{|c|c|c|c|c|}
\hline $\begin{array}{l}\text { Hypothes } \\
\text { es }\end{array}$ & Path & $\begin{array}{c}\text { Standardize } \\
\mathrm{d} \\
\text { Coefficient }\end{array}$ & $\begin{array}{c}\text { Critical } \\
\text { Ratio } \\
\text { (t-value) }\end{array}$ & Result \\
\hline $\mathrm{H} 1$ & $\begin{array}{l}\text { Moral Intensity } \rightarrow \\
\text { Ethical Judgment }\end{array}$ & .59 & $7.84 * * *$ & $\begin{array}{c}\text { Significa } \\
\text { nt }\end{array}$ \\
\hline $\mathrm{H} 2$ & $\begin{array}{l}\text { Idealism } \rightarrow \text { Ethical } \\
\text { Judgment }\end{array}$ & .22 & $1.97^{* *}$ & $\begin{array}{c}\text { Significa } \\
\text { nt }\end{array}$ \\
\hline $\mathrm{H} 3$ & $\begin{array}{l}\text { Relativism } \rightarrow \\
\text { Ethical Judgment }\end{array}$ & .20 & 1.45 & $\begin{array}{c}\text { Not } \\
\text { Significa } \\
\text { nt }\end{array}$ \\
\hline
\end{tabular}

Notes: ${ }^{* *} p<.05, * * * p<.001$ (two-tailed test).

\section{Discussions and Conclusion}

This current study was intended to provide a better understanding regarding the simultaneous impact of moral intensity construct and ethical orientation components on ethical judgments among the future auditors in Malaysia. The future auditors' moral intensity perception seem to vary between each scenarios and influence by the ethical issue (scenario) presented to them. The analysis revealed that the future auditors have identified the different level of moral intensity issues among the two scenarios and advocated different predictive power of the moral intensity components. 
This result is consistent with previous studies conducted by Sweeney \& Costello (2009) and Leitsch (2006). The results support the view that moral intensity is strongly related to auditors' ethical judgment. Auditors who have a strong sense of moral intensity would exercise more ethical concern than those who have a lower moral intensity. These findings are consistent with past studies which associated the high level of moral intensity with high level of ethical judgment and the other ethical decision making process i.e. ethical sensitivity, ethical intention and ethical behavior(e.g. Singh et al., 2007; Sweeney \& Costello, 2009; Valentine \& Bateman, 2011).

In regard to the personal ethical orientations, only idealism ethical orientation is significantly influence the future auditors' ethical judgments in Scenario 1 and Scenario 2. The auditors' level of idealism was higher than the level of relativism. In which, this finding indicates that the future auditors are more concern towards the human welfare in making up their ethical judgments. Idealistic mind enhances them to be more sensitive towards the ethical issues thus make them to support the ethical correct actions and will not compromise with any actions which could give harms to others.

This type of orientation is deemed suitable for the auditors as by profession, auditors are observant of rules or in line with deontological theories approach. In other words, rules and regulations guide them in perceiving ethical problems and are more sensitive towards ethical issues. The idealist orientation of an individual could help the future auditors to follow accounting and auditing standard, rules and regulations besides other statutory and professional requirements in performing their duties. Such formalities shape them to be more perceptive of ethical problems and create a more law-abiding mindset when dealing with a variety of unethical situations.

In conclusion, as the accounting students would be the potential future auditors, they owe future ethical obligation to the public to perform their duties with objectivity and trustworthiness. Therefore, the understanding regarding the importance of the variables under study (i.e. moral intensity and personal ethical orientation) may enhance the process of recruiting and training auditors as well as heighten the level of auditors' ethical concern. Overall, it is expected that the results of this study could enhance the future auditors' ethical judgments and could restore the public confidence on the auditing profession in the next future. In addition, it is hoped that the findings could provide a platform in supplying future profession with high integrity and ethical value citizen, as stipulated in the national agenda of national key result area (NKRA).

\section{Limitation and Suggestions for Future Research}

There are several limitations for this research study. First, the external validity of this study is limited since the case contains less information than the real audit environment. In the real audit environment, much richer information will influence audit judgment performance. Second, this study included primarily audit trainees from accounting degree students with a modest sample size. The use of auditing students must be interpreted with caution and reservation (Abdolmohammadi \& Wright, 1987).

\section{References}

Cohen, J. R. \& Bennie-Martinov N. (2006). The applicability of a contingent factors model to accounting ethics research. Journal of Business Ethics, 68: 1-18. 
INTERNATIONAL JOURNAL OF ACADEMIC RESEARCH IN BUSINESS AND SOCIAL SCIENCES Vol. 8, No. 12, Dec, 2018, E-ISSN: 2222-6990 C 2018 HRMARS

DeZoort, T., Harrison, P. \& Taylor, M. (2006). Accountability and auditors materiality judgments: The effects of differential pressure strength on conservatism, variability, and effort. Accounting, Organizations and Society, 31 (4/5): 373-90.

Fernando, M. \& Chowdhury, R.M.M.I. (2010). The relationship between spiritual well-being and ethical orientations in decision making: An empirical study with business executives in Australia. Journal of Business Ethics, 95(1), 1-15.

Forsyth, D. R. (1980). A taxonomy of ethical ideologies. Journal of Personality and Social Psychology, 39 (July), 175-184.

Greenfield, A. J., Norman, C. \& Wier, B. (2008). The effect of ethical orientation and professional commitment on earnings management behavior. Journal of Business Ethics, 83, 419-434.

Jones, T. M. (1991). Ethical decision making by individuals in organizations: An issue- contingent model. Academy of Management Review, 16, 366395.

KPMG International. (2012). The global center for leadership \& business ethics presents Laureate awards to Whitehead, Cadbury and Robèrt. Retrieved July 15, 2012, from http://www.kpmg.ca/en/news/pr20050601.html

Kung, Fan-Hua \& Huang, Cheng-Li. (2013). Auditors moral philosophies and ethical beliefs. Management Decisions, 5(3), 76-92.

Ludlum, M. P. \& Moskaloinov, S. (2005) Russian student views on business ethics: Post-Enron, College Student Journal, 39, 156165.

Marques, P. A. \& Pereira, J. A. (2009). Ethical ideology and ethical judgments in the Portuguese accounting profession. Journal of Business Ethics, 86: 227-242.

OFallon, M. J. \& Butterfield, K. D. (2005) A review of the empirical ethical decision-making literature: 19962003, Journal of Business Ethics, 53(4), 375413.

Singh J. S., Vitell S. J., Al-khatib J. \& Clark I. (2007). The role of moral intensity and personal moral philosophies in the ethical decision-making of marketers: A cross-cultural comparison of China and the United States. Journal of International Marketing, 15( 2), 86112.

Singhapakdi, A., Vitell, S. J. \& Franke, G. R. (1999). Antecedents, consequences and mediating effects of perceived moral intensity and personal moral philosophies. Journal of' the Academy of Marketing Science. 27(1), 19-36. 
INTERNATIONAL JOURNAL OF ACADEMIC RESEARCH IN BUSINESS AND SOCIAL SCIENCES

Vol. 8, No. 12, Dec, 2018, E-ISSN: 2222-6990 C 2018 HRMARS

Suryaningrum, D. H., Hastuti, S. \& Suhartini, D. (2013). Accounting student and lecturer ethical behavior: Evidence from Indonesia. Business Education \& Accreditation, 5(1), 31-41.

Sweeney B. \& Costello F. (2009). Moral intensity and ethical decision-making: An empirical examination of undergraduate accounting and business students. Accounting Education, 18(1), 7597.

Westra, L.S. (1986). Whose Loyal Agent? Towards an Ethic of Accounting. Journal of Business Ethics $5: 119-128$. 